\title{
Folklore, Superstitions and the Sea
}

\section{Louis Arthur Norton}

Les gens qui gagnaient leur vie en mer ou qui vivaient près de la mer, c'est-à-dire les pêcheurs, les marins marchands et leurs familles, $s$ 'inquiétaient de ses bienfaits et de ses risques. C'est ainsi qu'ils ont élaboré de nombreuses stratégies pour faire face à l'inconnu, y compris des tabous, des rituels et des présages qui pourraient prévoir l'avenir. Bon nombre de ces stratégies, qui se définissent davantage comme superstitions, étaient destinées à leur porter chance ou à éviter la malchance. Certaines superstitions devaient prévoir des situations imminentes tandis que d'autres n'existaient que pour convenir aux coutumes. Le récit suivant expose plusieurs superstitions maritimes ainsi que leurs origines présumées - à la fois sérieuses et, dans certains cas, amusantes.

Although superstitions historically permeated all aspects of society, those who laboured upon the sea, in particular, had often-unique sets of beliefs that fostered acts and rituals that were passed down through folklore. This article will explore some of these superstitions of maritime origin, many of which are still found in everyday land-based society.

A superstition is a belief or set of beliefs invented by humans in their struggle to understand their relationship to their surroundings. They have a commonality of need and are the products of signs or symbols that correlate with observed events. Generally a superstition produces an activity to induce or prohibit an occurrence. This may be a physical action and/or the recitation a mnemonic to influence its performance. Taken one step further, superstition is the origin of tenets based upon mystery and faith or what mankind calls religion. The performance of some prayers or rituals is designed to bring about a change in fortune. Therefore superstition is a device to keep truth from the door, a system of vast notions and complex concepts. The awkward and twisted part of one's world of beliefs sometimes leaves little room for reality. Instead the human brain is vaulted above veracity and conjures up the fanciful.

Sailors plied the oceans to provide food, spread civilization, establish commerce and, at times, participated in war. Mariners shared a common need: inducing a positive event or perhaps prohibiting an unpleasant outcome, changing fortune, and hopefully predicting the unpredictable. These seafarers were obsessed with omens, finding the causes of good and bad luck, dealing with tragedy and predicting weather.

The Northern Mariner/Le marin du nord, XXVI, No. 1 (January 2016), 21-30 
The earliest superstitions had a pagan origin. For example, throughout the epic poem The Odyssey, Homer alludes to numerous signs, omens, and predictions in which the Greeks placed their trust. The Greek gods sent many omens, signs, and predictions to allow the Greeks prepare for various eventualities. The characters believed that the appearance of certain birds in a critical hour was a sign from a Divinity. A special bird in flight could be an omen, a message from the gods; The Odyssey's Theoklymenos tells Telemachos that "not without a god's will hath this bird flown out on the right, for I knew when I saw him that he was a bird of omen." Therefore omens and prophecies from classical literature lent credence to mariners that they were not operating in a world with much room for free will. It was no wonder that birds such as sea eagles, gulls, storm petrels and albatrosses were looked upon as giving signs of future events.

\section{Fishermen}

Fishermen are peculiar in maritime culture. Sailors make their living by passing through the seas, but fishermen farm these seas for a finny harvest. They observe and chronicle irregular events, enigmas that occur at unexpected times and unanticipated places. They seek the cause of these new phenomena - or at least an explanation. Most fishermen accepted dogma and fables that, at the time, made sense. This was the genesis of superstitions of the sea.

Superstition is ... a quality that seems indigenous to the ocean. Few common mariners are exempt from its influence, in a greater or less degree; though it is found to exist, among the seamen of different people, in forms that are tempered by their respective national habits and peculiar opinions. [A sailor may have] his secret rites, and his manner of propitiating the gods of the wind; [others may see] . . the spirits of the dead in the storm, ... the cries of a lost messmate in the gusts that sweep the waste he navigates. . . . unable to shake entirely off the secret influence of a sentiment that seems the concomitant of his condition. ${ }^{2}$

Luck was an elusive entity that produced success or failure. When a fisherman spat upon the first fish caught, released it unharmed to swim again, then saved the biggest fish to be processed last, these were actions thought to bring good luck. When the first fish taken was to be returned to the sea in reverence, it was a sacrifice to the god of the sea, Poseidon, although few fishermen were aware of this. Saving the largest of the catch to be processed last was also done in deference to the gods. If the first fish caught was female, that would be very indicative of a good trip to follow. Perhaps fish are not biting. It was then advised to throw a fisherman into the water and then haul him out. The fish were expected to come around out of curiosity. ${ }^{3}$

\footnotetext{
Homer, The Odyssey, Chapter 15.

Cooper, James Fenimore, The Red Rover, ((London, 1827) Chapter XV opening paragraph.

${ }^{3}$ Potter, Carole, Knock on Wood and Other Superstitions, (New York, 1989), 79.
} 
Later that afternoon, as the sunlight dimmed, the fisherman saved the largest fish of his catch to be cut and dressed last, to assure that more big fish would be taken tomorrow. When his hold was full he raised a broom to the top of the mainmast to signal the remaining fishermen that he had "swept the banks clean of fish" and would promise a safe return passage.

Individual fish species had their own lore. When codfish bit with fervor, a storm was brewing. Herring fishermen would wrap inedible portions of herring in paper before discarding them. It was believed that the bones would knit together and the reconstituted fish would summon its fellows thus insuring a good future catch. ${ }^{4}$ Some believed that swallowing a live goldfish would cure a person of whopping cough. ${ }^{5}$

Most superstitious fishermen tried to identifying the source of bad luck and avoid it. The best known was naming a "Jonah," the allegorical Old Testament figure. ${ }^{6}$ An anonymous ship served as Jonah's vehicle escape from God, but there was no escape from the pervasive God of the Hebrews. Jonah stayed in solitude in the bowels of the ship and slept. Before long the ship encountered a terrible storm. The crew identified the Hebrew foreigner Jonah as a likely cause of the tempest, but he also might be their means of salvation. The men asked, "what shall we do unto thee, that the sea may be calm unto us?" Jonah responded, "take me up, and cast me forth into the sea; so shall the sea be calm for you; for I know that for my sake this great tempest is upon you." ${ }^{8}$ At first the men hesitated at throwing Jonah overboard to his probable death and desperately rowed to bring the ship to land, but they failed to reach land, "so they took up Jonah and cast him forth into the sea; and the sea ceased from its raging."' This story was the basis of all mariners' quests to identify a Jonah and cast out bad luck from their ship. A cursed Jonah was to be sacrificed as a putative scape goat in order to purge the wooden-walled community of evil. ${ }^{10}$

When terrible misfortune occurred, the fishermen resorted to a lot-drawing method to unearth a hidden Jonah. The cook would place a coin, nail or sliver of wood in the ship's bread or pudding. The man who received the unwelcome token was thought to be a Jonah and a bad omen for the future. The fisherman was then obligated to exorcise the curse by carrying his bed sack on deck (also known as jerking the straw), setting it afire, and fumigating himself with all manner of materials commonly found on ships while reciting strange magic words.

The mark of a Jonah could take many forms. For example, a fisherman who was consistently unlucky on voyages was classified as a Jonah. Being a foreigner, having different physical characteristics or even wearing certain colors like black nippers or mittens could brand a man a Jonah on fishing boats, the color black being associated with death. Because of this, before setting sail fishermen avoided speaking to priests

\footnotetext{
${ }^{4}$ Cavendish Richard, Man. Myth and Magic, (New York, 1970), 986.

${ }^{5}$ Ibid., 987.

${ }^{6}$ King, Dean, A Sea of Words (New York, 1995), 217.

Bible, Book of Jonah, 1:11.

${ }^{8}$ Ibid., 1:12.

${ }^{9}$ Ibid., 1:15.

${ }^{10}$ Bible, Leviticus 16:8 - 10. A goat sent into the wilderness after the Hebrew high priest had symbolically laid the sins of the people upon it.
} 
garbed in black or lawyers who were considered grim serious men. They engender an aura of demise around them. If a fisherman broke a looking glass, spilled salt at dinner, drove a nail on Sunday, or left a half-filled bucket of water on deck, especially with a mackerel in it was considered a Jonah sign. Something as simple as leaving the mother-ship in a fishing dory in a direction contrary to the custom of the rest of the crew, called attention to one's self. Certain off watch activities of fishermen led to suspicion of "Jonah-hood" such as playing of checkers, making toy boats, or playing the fiddle. And so fishermen lived with their multitude of superstitions.

\section{Ships}

Strangely an entire vessel might be declared a Jonah if it became chronically unprofitable. Because a ship represented a substantial investment, the solution for dealing with a Jonah ship was relocating to another port and changing the craft's name. Also perhaps modifying the vessel in some way like altering its use. For example, a green unsuccessful Grand Banks fishing schooner called Netter could reappear as a profitable black coastal collier now known as Coal Carter. There were certain name choices, however, that were avoided. "Nobody would risk taking a risk on a ship having the word 'ice' in any part of its name, because . . . [it was] considered unlucky." 11

Superstitions involving name changing had potential contradictory risks as well. ${ }^{12}$ Some mariners considered changing a vessel's name after she had sailed as unlucky. It was difficult to find men who were willing to work on renamed ships. The origin of the renaming superstition was pagan. It was deemed an attempt to sneak past the gods, escape their attention and avoid their retribution for pass misbehaviors. This meant that a proper renaming ceremony had to take place that included a clear entreaty to the gods to acknowledge the boat's new name and there was no ulterior motive. Once a vessel has received a new name, the old one must never to be mentioned again or some calamity will likely occur.

Shipbuilding had its own set of superstitions that combined to become custom and later, tradition. The mounting of figureheads on the ship's bow evolved from the carving and painting eyes on the bows to guide vessels safely home. The origin of this custom may date back to the Greek or Roman "oculus." Interpreted as both the evil or all knowing eye. ${ }^{13}$ Fishing boats were generally devoid of much ornamentation, but the hawse pipes was often painted to resemble eyes that would surely guide the vessel safely home. Incorporation of a timber from a successful vessel into a new one being built on the ways passed on the good destiny. When a new mast was installed, a "lucky" garland of flowers surrounded it. A horseshoe nailed in the upward " $U$ " position on the bowsprit of a vessel will bring good fortune.

\footnotetext{
${ }^{11}$ Drake, Samual Adams, The Pine-Tree Coast, (Boston, 1891), 193.

${ }_{12}$ Lamont-Brown, Raymond, A Book of Superstitions, (New York, 1995), 106.

13 The earliest written references to the evil eye occur on Sumerian clay tablets dating to the third millennium BC.
} 
Admiral Horatio Nelson allowed his crew to nail a horseshoe to a mast of HMS Victory. (Presumably the object brought fortune to the warship, but tragedy to Nelson.) Asian fishermen nailed a dried crab over their cabin door as variation on the theme of influencing their fishing craft's kismet. ${ }^{14}$

In ancient times a member of the priesthood attended launchings carrying a lighted torch, a special libation and some brimstone to acclaim the vessel as devoted to a pagan deity whose likeness was carved into the prow..$^{15}$ (This launching custom remains, although modernized, and retains a semblance of the antiquated ceremony.) A vessel that stopped its slide to the sea on the launch-way after the christening ceremony was a bad omen. The gods likely thought the shipwrights' efforts unworthy of sailing on their ocean.$^{16}$ When stepping a mast, a coin or coins were placed under the mast at the keelson to assure its good fortune. Perhaps more important, if the ship met an unfortunate fate and all hands were lost, the coins could be used by the crew to pay the ferryman Charon for safe passage across the mythological lower world River Styx. These familiar superstitions and their attendant rituals survive, but few people remember their pagan origins.

\section{Death}

The classic dark poem, Samuel Taylor Coleridge's The Rime of the Ancient Mariner, was based upon maritime superstition. ${ }^{17}$ The seafarer returning from a long arduous voyage narrated a story at a wedding that created sensations of the supernatural, danger or tranquility, in different parts of the poem. The tale began with his vessel departing on its journey. In the poem the Mariner recalls a voyage in which a gigantic storm rose and pushed the ship southward to a frigid land of mist and snow where the ship was hemmed in a maze of ice. Suddenly the sailors encountered an albatross flying around the ship. The ice cracked, split and a favorable wind propelled the ship out of the frigid regions and into a dense patch of fog. The albatross followed behind the vessel and it was considered a symbol of good luck to the sailors. The Mariner shortly confesses that he shot and killed the albatross with his crossbow.

At first, the sailors were furious with the Mariner for having killed the bird that appeared to make the breezes blow. In time the wind pushed the ship into a quiet sea. The ship was now idle like a ship painted upon an ocean. The men had no water to drink and horrible hallucinations occurred. The sailors blamed the Mariner for their predicament and hung the dead albatross around his neck like a cross. The Mariner saw a tiny speck on the horizon that resolved into a ghostly ship moving toward them. This turned into a maritime nightmare of all sorts of creatures and wild colors that ended when he found himself able to pray - that is, finding his faith. With that the corpse of the albatross fell from his neck and sank into the sea. "He prayeth best, who

\footnotetext{
${ }^{14}$ Cavendish Richard, Man. Myth and Magic, 2512.

${ }^{15}$ Knowlson, T. Sharper, The Origins of Superstitions and Customs, (London, 1910), 104.

${ }^{16}$ Ironically the icon of United States Navy, the frigate Constitution, suffered this humiliation at its launching in October 1797.

${ }^{17}$ Coleridge, Samuel Taylor, The Rime of the Ancient Mariner, (New York, 2013).
} 
loveth best All things both great and small; For the dear God who loveth us, He made and loveth all." ${ }^{\prime 8}$ This late eighteenth century poem reflected the superstition that albatrosses contained the soul of dead sailors and slaying such a bird was considered bad luck for mariners. ${ }^{19}$

One common superstition among seafaring men involved sharks that relentlessly followed a vessel. It was thought that sharks can "scent" death therefore it was a sign that someone on board was going to die. In reality sharks often follow vessels because scraps of food and other leavings are thrown overboard thus attracting them.

Superstitions concerning ghosts led to burial at sea ceremonies. When a man died at sea he was sewed up in his hammock as a shroud. The last stich was placed through the septum of his nose. If the man was still alive, he would shake off the covering and appear either as a ghost or a revived former dead man. If the sailor was confirmed as deceased, weights were placed in the shroud to sure that the corpse sank to the depths of the sea, a locale called Davy Jones' (Devil Jonah's) locker. The spirit of the sailor would then enter "Fiddler's Green," an underwater heaven for mariners presided over a kindly witch known as Mother Carey. If a fierce storm appeared on the ocean above, Mother Carey would transform the seamen into storm petrels so that they could squawk and swoop about a ship to warn them of the approaching danger.

After a man was lost at sea, and an appropriate time had passed, his possessions were auctioned to the crew. The seaman who acquired personal items would not dare to use the item until the vessel had docked at home for fear of offending the ghost of their former shipmate. ${ }^{20}$ Related to this was the superstition that a death focused the mind of those left behind. Shipmates often talked of the departed, relating dreams or unusual behavior that might have predicted a calamity. A shipboard accident made everyone remember some little circumstance that might be considered a forewarning. "When I went to the galley to get a light, I found the cook inclined to be talkative, so I sat down on the spars, and gave him an opportunity to hold a yarn. I was the more inclined to do so, as I found that he was full of the superstitions once more common among seamen, and which the recent death had waked up in his mind. . . He believed that few men died without having a warning of it, which he supported by a great many stories of dreams, and the unusual behavior of men before death."21

The "stone fête ceremony" was a mourning custom grounded in superstition. A grieving captain's family would prepare a feast a year following the death of a captain who was lost at sea. Prior to the banquet a cooper would build a cask, preferably from wood salvaged from the lost vessel or from a captain's possession. The barrel would be vaguely rigged to resemble a ship. One of the guests would receive the "honor" of being appointed first mate and he in turn selected a crew. The "mate and crew" then spent the evening drinking, and singing, dragging the mock vessel from tavern to tavern. At an appointed hour the crew would smash the cask

\footnotetext{
${ }^{18}$ The Rime of the Ancient Mariner, closing stanza

${ }^{19}$ King, A Sea of Words, 74.

${ }^{20}$ Dana, Richard Henry, Two Years Before the Mast, (New York, 1899), Chapter 6, "Loss of a Man - Superstition."

${ }^{21}$ Lovette, Leland Pearson, Naval Customs, Traditions and Usage, (Annapolis, MD, 1939), 267.
} 
with stones until it fell apart thus releasing the captain's spirit from his ship so that he might enter heaven.

Another superstitious shipboard destruction rite was called the "dead horse ceremony." ${ }^{22}$ In this case the crew of a vessel beat and burned a mock straw horse suspended in the rigging after working off their advanced wages that paid bills left behind on shore. The demon that needed to be released was economic, a symbol of fiscal freedom however temporary.

\section{Weather}

Weather could be a close friend and an unforgiving enemy. Superstitions about fog, storms, doldrums, and rogue waves abound. Cloud formations, sky color, and wind directions all conjure superstitions relating to weather prediction. Leaving a hatch cover bottom-side up or allowing a hatch to fall into the hold would invite huge rogue waves. Whistling on deck might just provoke a hurricane, but if there was no wind at all, one could sometimes whistle up a breeze. Scratch the aft side of the mainmast with a knife would assure a fair wind. At night helmsmen plotted the direction of shooting stars that they believed pointed toward fair winds. During the day the crew watched for "sundogs" (small halos around the sun), as a sign of foul weather. Carrying an umbrella on shipboard was considered very bad luck, a prelude to extremely violent wind.

Adverse weather occasionally was attributed to xenophobia, a weather-related variation of the Jonah concept. Sailors of Finnish and Lapland ancestry were thought to be wizards who had the power over winds and decide to produce a headwind that slowed the progress of the ship. ${ }^{23}$ If their country of origin was found out, the crew badgered the man into turning a breeze to the ship's favor. Similarly men with certain Scottish family names such as Coull, Ross, and Whyte were thought to be unlucky on the fishing grounds. ${ }^{24}$

Sailor's doggerels and old saws abounded as aids to remember the meaning of observed events. These verses had their origins in superstitions and some proved useful at sea when the sailors had no reliable way of predicting the weather. "Red sky in the morning, sailors take warning; Red sky at night, sailor's delight" was perhaps the most familiar. Two variations are, "If the morning is marked by an easterly glin, the evening will bring rain to wet your skin" and "If in the southwest you see a smurry sky, douse your kites, for a storm is nigh.".25

\footnotetext{
22 Ibid., 49.

${ }^{23}$ Beck, Horace, Folklore and the Sea, (Middletown, CT, 1973.) Discrimination was practiced against sailors of other nationalities in various fishing communities. Joseph Conrad's novel The Nigger of the Narcissus addresses this behavior in a merchant vessel.

24 Rappaport, Angelo, Superstitions of Sailors, (London, 1928), 258.

25 Goode, George Brown, The Fisheries Industry of the United States, (Washington, DC, 1887).

Section IV( The Fishermen), 68. A glin is a thick overcast; a smurry sky is hazy with a greasy look.
} 


\section{Religion}

Mentioning one's fishing success to others was arrogance and might be objectionable to God. In like fashion, fishing everyday was a sign of greediness and might upset God's bounty in the sea. (That superstition was based upon common sense and has turned out to be prophetic.)

Sailing on specific days of the week had superstitious significance. One avoided setting sail on a Friday either because it was the day of Christ's crucifixion or perhaps a pagan justification. The day "Friday" was derived from Frigga (Freya), the vengeful wife of the Norse god Odin. It was believed that she would do harm to men who sailed on her day. Other days were 1 April, the putative birthday of Cain and the day they he slew Able; the second Monday of August, the anniversary of the destruction of Sodom and Gomorrah; 31 December when Judas hanged himself after his betrayal of Jesus. Fishing on this day was supposed to make it likely to snag the body of a corpse wrapped in sailcloth from the deep. Another fateful date was Candlemass, the Christian festival that commemorates the purification of Mary forty days after the birth of Jesus. According to Old Testament tradition, women were considered unclean after the birth of a child, but could be ritually cleansed after a strictly specified waiting period. ${ }^{26}$

Candlemass also has heathen roots. Candlemass, February the second, is also a cross quarter day, halfway between the winter solstice and the spring equinox. Certainly sailing on this time was ill advised because the weather was more likely to be unkind at this time of year. ${ }^{27}$

Superstitions surrounded the number thirteen. Its origin was believed to be from the Last Supper during which Jesus dined with the twelve apostles prior to his death. Similarly a Norse myth told of twelve friends of the god Odin who dined together, but their banquet was crashed by a thirteenth person, Loki, the god of evil and turmoil. Therefore combining two negative portents mentioned above, it was particularly ominous to set sail on a Friday the thirteenth.

Combining faith and superstition, votive ship models were given to churches and suspended aloft over the congregation so that they might also receive God's blessing. ${ }^{28}$ More directly, many fishing communities still set aside one day for a blessing of the entire fleet by a prelate. Certainly fishermen commonly wore amulets and religious medals. Ships in bottles were the craft of merchant sailors, but votive crucifix scenes in bottles were the more prevalent and perhaps useful craft of the fishermen. Finally one should note that earliest Christian symbol was a stylized fish, an emblem widely used during the first three centuries of the nascent church. Fish, a common food of the Galilee region, played a prominent role in Jesus's ministry.

\footnotetext{
26 Leviticus 12.

27 Rappaport, Superstitions of Sailors, 260.

28 The Our Lady of Good Voyage Church in Gloucester, Massachusetts has a statue of the Virgin Mary cradling a fishing schooner in her left arm on the ornate pediment high above the church's main entrance.
} 


\section{Miscellany}

Finally there was a group of superstitions that had little bearing on the sailor's immediate welfare, but were strictly adhered to. Whistling onboard a fishing schooner under sail was permissible in a flat calm as a means of summoning a favorable wind. ${ }^{29}$ Carry salt or an amber stone in your pocket to promote good luck when fishing. Avoid being hit by the excrement of the sea gulls or misfortune maybe your lot. Paradoxically some fishermen considered a sea gull "strike" a sign of good luck, a common but unpleasant occurrence. Never sit on an upside-down bucket on deck or pass a flag to a fellow sailor through the rungs of a ladder or misfortune will be sure to follow. Always leave a few fish scales on the deck when cleaning up to attract fish for the next trip.

Becoming seriously ill at sea could be disastrous; therefore many sailors "practiced" preventive medicine based upon a few superstitions or old wives' tales from shore related to preserving one's health. For example, a potato in a pocket warded off rheumatism; a nutmeg cured scrofulous, an infectious disease of lymph glands that was commonly seen on the neck. For seasickness sailors drank seawater, crewed on a dry biscuit, drank tea, ate pickles, and consumed a lot of pork fat. Ingesting the liquid from a barrel containing the collected livers of codfish cured anemia. Drinking milk while eating fish poisons the consumer. ${ }^{30}$ (This seems contrary to the popularity of fish chowder among seafarers however.) Drinking plenty of "iron water" maintained your health on board. ${ }^{31}$ ("Iron water" was rainwater in a barrel on the deck that also contain an old cannon ball. The rusting iron ball provided just the right "dose of iron" to prevent all sorts of ailments.) Wear earrings cured poor eyesight, but if only one eye was bad, the sailor placed the earring on the side opposite the weak eye. ${ }^{32}$ Men had their haircut when the moon was increasing in size to insure that it would not be lost prematurely. Lucky bones, lucky stones, and certain fruit pits acted as prophylactics, a good thing to carry for pleasurable evenings on shore. A freshly cut piece of pine rubbed into a fishhook or fish dressing-wound enhanced healing. A sailor counted the warts found on his body aloud so that they would decrease in number.

The negative connotation of thirteen traditionally was not necessarily true among American sailors. Its thirteen original colonies became the United States. The dominant symbol of Great Seal of the United States is a bald eagle that holds a quiver of thirteen arrows in one talon and an olive branch containing thirteen leaves in the other. Above its head is a round frame containing thirteen stars. The nation's motto, E Pluribus Unum, has 13 letters that appear on a ribbon near the eagle's head. The

\footnotetext{
29 Lamont-Brown, Book of Superstitions, 107.

30 Cavendish, Man. Myth and Magic, 987.

31 The taking cod liver oil was a preventive medicine measure in fashion not long ago.

${ }^{32}$ Motor and sensory functions of the central nervous system crossover, that is the right or left sides of the body are generally controlled by the opposite side of the brain. Although the earring superstition had no basis in fact, it did have neuroanatomic intuitiveness.
} 
American flag features thiteen stripes. Therefore most Yankee sailors considered thirteen a patriotic number. ${ }^{33}$

When a clock struck too many times, it usually indicated that it was malfunctioning, but in a nautical tradition, it commonly happened when ringing in the New Year on a ship. The sounding of eight bells can mean midnight onboard a vessel, a time to change watch on shipboard. But on 31 December, by custom the oldest man in a ship's company had the duty of striking eight bells at midnight followed by the youngest crewmember immediately striking eight additional bells to announce the New Year. This was the only time that sixteen bells were sounded. The superstition was that this action would bring a year's good fortune to the vessel and crew.

Fishermen were preoccupied with observing nearly everything around them, seeing omens in every sign, action, or inaction. One American state submitted to an occupational superstition by providing a good luck symbol for its fishermen, a golden quasi-spiritual fish. A venerable gilded wooden codfish hangs in the House of Representatives in the State House of the Commonwealth of Massachusetts. It was first placed in the Old State House that was the seat of government prior to the Revolution. "The Sacred Cod" moved with the changing halls of government in 1798 and again in 1895. Three representatives in a procession escorted by the sergeant-atarms ceremoniously carried the wooden icon. "As they entered the new chamber, the venerable members of the legislature rose and gave a vigorous round of applause." ${ }^{34}$ Superstition suggests that, as long as the emblem hangs in this place of honor, the inhabitants of the Commonwealth would have good fortune.

\section{Conclusion}

Many men who "went down to the sea in ships" believed in supernatural powers, occult forces and spirits that were regulated through rituals. They participated in ceremonies that produced hope, confidence and peace of mind, a form of protection from ominous vulnerabilities. When the mariners returned ashore, many of their superstitions took root in every day society and spread across much of the world. Few of these landsmen realized their maritime origin, but they have become a long lasting communal gift - a bequest from the deep.

\footnotetext{
${ }^{33}$ In 1894 American navy enlisted men's bell-bottom trousers were designed with a "broadfall," or flap held in place by thirteeen buttons. The popular belief was that they represented the original thirteen colonies of America. To strengthen this case uniform designers hid a fourteenth stealth button behind the broadfall so the button-colony connections would still be upheld, not to mention holding up their trousers.

${ }^{34}$ Kurlansky, Mark, Cod: a Biography of the Fish that Changed the World, (New York, 1997),79.
} 